\title{
RECONNAISSANCE GEOLOGIC MAP OF THE HOTCHKISS AREA, DELTA AND MONTROSE COUNTIES, COLORADO
}

By

W. J. Hail Jr.

MISCELLANEOUS GEOLOGIC INVESTIGATIONS

MAP I-698

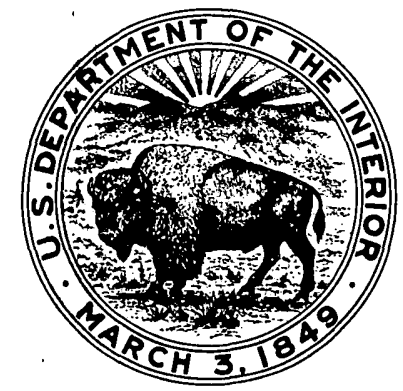

